\title{
Determinants Underlying the Selection of Certain Food Products in Urban Households of Seniors in Poland
}

\section{Introduction}

Population ageing is considered as the key demographic trend of the $21 \mathrm{st}$ century. The reversal of the demographic pyramid in highly developed countries has led to the emergence of the segment of the elderly, also referred to as the senior or silver segment, in the market. Therefore, old age problems as well as food intake and nutritional patterns of seniors are currently being addressed in a number of scientific studies, also given the increase in life expectancy observed in recent years in the world. Moreover, Poland's demographic situation requires measures to improve living conditions in the fundamental aspects of social life of this age group. According to Tsai, Liou and Chang, consumption of food products and an adequate diet of people aged $65+$ are decisive for the proper functioning of the body, and may contribute to delaying the natural ageing process [Tsai, Liou and Chang 2006, pp. 73-74]. Over the last two decades, many interesting changes can be noted as regards food products consumed by Polish seniors. These developments evince the rationality of consumption, increased attention to health prophylaxis, well-being, comfort, including changes in lifestyle and nutrition.

The variability of consumer expectations over time is also noteworthy. In this context, consumer behaviours of seniors differ from purchasing decisions made by younger consumers. Nevertheless, it can be stated that market behaviours of an increasing number of seniors are similar to their behaviours during their working lives. In addition, age perceived by senior consumers is now frequently younger than their calendar age, although this is not the rule. 
This article addresses the issue that focuses on consumption of selected food products in seniors' households. The primary goal is to analyse food expenditure and shopping frequency among surveyed Polish seniors as well as the key factors affecting their decisions in this regard. The analysis is based on the questionnaire survey conducted by the author in 2014-2015 among people aged 65+ in Poland.

This article is a research exercise. Its structure is as follows. First, food consumption in seniors' households is briefly highlighted in theoretical terms. Afterwards, the research methodology and assumptions, together with the characteristics of the research sample, are synthetically discussed. Further, the focus is on examining food intake in the households surveyed, shopping frequency, and the key determinants taken into consideration by people aged $65+$ when deciding to buy food products. A conclusion of the analysis and major findings end this article.

\section{Food consumption in households - theoretical framework}

The sine qua non condition for the human body to function properly is food consumption; therefore, food is a part of the product group that must be present in human consumption and in every household's consumption as it caters for viscerogenic needs. It should be emphasised, however, that food does not have its substitutes. Hence, regardless of a household's income situation, it will always be a priority in the hierarchy of needs although it will not necessarily dominate the consumption structure. When their income situation deteriorates, households tend to first and foremost cater for their basic (lower-order) needs including food needs (the so-called ratchet effect), simultaneously reducing their higher-order needs.

According to the key theories and concepts of human needs hierarchies proposed, inter alia, by Maslow [1954], Alderfer [1972], McClelland [1975] and Max-Neef [1991], food needs are physiological human essentials and are considered the most important needs of each individual the fulfilment of which determines the development of further needs [Zalega 2012, pp. 61-62].

During the last two decades, food consumption in Poland has undergone substantial quantitative and qualitative changes. It can be supposed that the future will see further developments. It must be remembered, however, that food and nutrition essentially determine human health and well-being. It is recognised that the lifestyle, together with its main component, namely diet, conditions as much 
as 50\% of human health (National Health Programme 2007-2015 - Annex to Resolution No. 90/2007 of the Council of Ministers of 15 May 2007).

In related literature, consumption is generally understood as the basic economic and social process that shapes both individual and collective social identity. Consumer needs in the food market are reflected as the purchasers' demand at particular market prices and disposable income. Consumers' food consumption patterns, on the other hand, reflect the actual level and structure of food consumption in given national socio-economic conditions. Food consumption patterns are markedly influenced by two groups of determinants: economic and non-economic. Economic factors including: disposable income of consumers, market prices of purchased products, savings, loans, and the supply of consumer goods play a crucial role. Non-economic determinants encompass, among others, geographical, cultural, social and occupational, and information and educational factors. Undoubtedly, food consumption patterns are also being increasingly influenced by dietary recommendations leading to rational nutrition as well as by new patterns of consumer behaviour that are the result of emerging alternative consumer trends such as cocooning, ethnocentrism, homogenisation, sustainable consumption [Zalega 2013, pp. 73-74, Zalega 2016, p. 230].

Food consumed in households comes from three main sources. First, it may come from a household's own farm or allotment garden, which is referred to as self-supply or natural consumption in the literature. Such self-consumption is one of the key factors affecting the eating behaviour in households, especially those of farmers and employee-farmers, while being of little importance in other groups of households [Gutkowska, Ozimek and Laskowski 2001, p. 116]. Another significant way of meeting food needs of the population is purchasing products in the market, also termed market or commodity consumption, financed from personal income of the population and covering only those food purchases that are made by consumers in the organised market. The third possible food supply source is social consumption, also called collective consumption, which is financed by the government. Funds for this purpose come from the central budget or financial resources of local authorities. Such assistance is usually entirely or partially free of charge [Zalega 2011, p. 120].

As independent market participants, senior consumers themselves define the amounts and structure of their expenditure on food products that are an effect of their needs, aspirations and financial capacities. Changes in food spending are, in turn, reflected in the quantity of food products consumed by household members. Nonetheless, it must be borne in mind that eating behaviours are differentiated depending on sex, age, personality traits, indicators of social and financial position, and regional and cultural contexts. 
With age, dietary recommendations are modified. Due to the changes in their bodies (slower metabolism, chronic illnesses), seniors often alter their eating habits and behaviours, which affects food purchases made by them.

\section{Conceptualisation of research}

The empirical material contained in this article comes from direct research conducted in the form of a survey questionnaire on a sample of 2537 households in 2014-2015 in ten Polish cities of various populations and sizes. In accordance with the research assumptions, the sample included persons over 65 years of age who took independent purchasing decisions in the market. In order to select the sample, the selective quota sampling procedure was used. The characteristics (quotas) covered by the research were: sex and age ${ }^{1}$.

This research method was chosen in view of the older age of respondents whose openness to new media (Internet, smartphone, i-Pod) often used in research is limited. The primary objective was to outline the quality of life, the structure of consumption and consumer behaviours of people aged 65+.

The survey was conducted among participants of the University of the Third Age (UTA) at state universities in: Warsaw, Kraków, Łódź, Poznań, Gdańsk, Katowice, Lublin, Białystok, Toruń and Wrocław, as well as among members of parochial clubs in parishes located in the Archdioceses of Warsaw, Kraków, Łódź, Białystok, Gdańsk, Katowice, Lublin, Poznań, Wrocław and the Dioceses of Warsaw-Praga and Torun.

Selection and characteristics of the research sample

The survey covered $71 \%$ of women, with only every third respondent being male. There were definitely more women than men and people aged 65-74 formed the largest age group in the sample ${ }^{2}$. Place of residence was also an impor-

\footnotetext{
${ }^{1}$ More on the methodology for the direct research and sample selection in: T. Zalega, Segment osób w wieku 65+ w Polsce. Jakość życia, konsumpcja, zachowania konsumenckie [People Aged $65+$ in Poland. Quality of Life, Consumption, Consumer Behaviour], Wydawnictwo Naukowe Wydziału Zarządzania UW, Warsaw 2016, pp. 163-168.

${ }^{2}$ The Anglo-Saxon literature uses the following division of older people: 1) young old - people aged $60 / 65-74 ; 2$ ) old old - people aged $75-84$; and 3) the oldest old - people aged 85 and more. The age classification in this study is similar to that proposed by the WHO. The author divided seniors into: 1) young old - people aged $65-74,2$ ) old old - people aged 75-84, and 3) the oldest old - people aged 85 and more. According to the UN, the conventional old-age threshold is 65 . It should be remembered, however, that old age is not just the number of years that a person has lived. We distinguish calendar (chronological) age and biological age. Many factors often cause very large discrepancies between chronological and biological ages.
} 
tant variable in the research. In line with the research assumptions, the sample comprised respondents who lived in the largest Polish cities.

Respondents were also asked about their level of education. The questionnaire included four categories of education: primary, basic vocational, secondary and higher education. Respondents with secondary education formed the largest group. Nearly 2/5 of those surveyed declared this level. Every fourth respondent was a university graduate, and those with basic vocational education represented a similar percentage. In the sample surveyed, people with primary education were the smallest group (11.4\%).

Nearly half of those surveyed were members of households consisting of two persons, while fewer than 2/5 represented three-person households. Every sixth respondent was a member of a single-person household.

The largest group of respondents included people whose monthly income per capita did not exceed PLN 2000. For every third respondent, the monthly income per household member ranged from PLN 2001 to 3000. In turn, every fourth person interviewed had a monthly disposable income per capita of between PLN 3001 and 4000. The smallest group of respondents included households where the income was above PLN 5000 per capita a month.

Nearly $45 \%$ of those interviewed described their economic situation as good, while $2 / 5$ as bad. Almost one in ten respondents regarded their economic status as very bad, whereas only one in ten assessed their material situation as very good.

\section{Food expenditure in the surveyed households of seniors}

Primary research showed that food expenditure dominates the total spending in seniors' households. The share of this expenditure stood at $29.2 \%$ in households of those aged $65+$.

The highest percentage share of food spending was noted for households in Białystok and Lublin, whereas the lowest was recorded for seniors' households in Warsaw. More accurate shares of such expenditure in the monthly budgets of seniors' households are reported in Table 1.

The differences in the share of seniors' food expenditure are largely dependent on the monthly income per household member (Spearman's rank correlation coefficient $\mathrm{r}=-0.286, p=0.01$ ). The lowest proportion of such spending was noted for seniors' households where the monthly income per capita exceeded PLN 4000.00. In this income group, more than $70 \%$ of seniors spent less than $1 / 4$ of their disposable income on food each month. 
Table 1

Share of food expenditure in the monthly household budget of seniors in Poland [in \%]

\begin{tabular}{|l|c|c|c|c|}
\hline \multicolumn{1}{|c|}{ Items } & Up to 25\% & $26-30 \%$ & $31-40 \%$ & $\begin{array}{c}\text { More than } \\
40 \%\end{array}$ \\
\hline \multicolumn{1}{|c|}{ Total } & 42.3 & 26.9 & 24.9 & 5.9 \\
\hline Income per capita: & 31.3 & 22.7 & 58.7 & 16.3 \\
Up to PLN 2000 & 34.4 & 31.2 & 27.1 & 7.3 \\
PLN 2001-3000 & 59.8 & 30.9 & 9.3 & - \\
PLN 3001-4000 & 72.7 & 22.8 & 4.5 & - \\
More than PLN 4000 & & & & \\
\hline Place of residence: & 44.8 & 29.5 & 21.6 & 4.1 \\
Warsaw & 43.7 & 27.7 & 22.4 & 6.2 \\
Kraków & 42.1 & 24.6 & 28.3 & 5.0 \\
Łódź & 43.1 & 28.3 & 22.8 & 5.8 \\
Poznań & 42.7 & 29.2 & 23.1 & 5.0 \\
Wroctaw & 42.2 & 26.2 & 25.0 & 6.6 \\
Gdańsk & 42.9 & 28.3 & 22.5 & 6.3 \\
Katowice & 41.2 & 24.9 & 26.9 & 7.0 \\
Lublin & 40.9 & 24.6 & 27.1 & 7.4 \\
Białystok & 39.4 & 25.7 & 29.3 & 5.6 \\
Toruń & \multicolumn{3}{|r}{} \\
\hline
\end{tabular}

Source: The author's research.

In seniors' households, the share of food expenditure was the highest in the group with incomes of up to PLN 2000 per capita. In the income group earning PLN 3001-4000 and above PLN 4000 PLN per person, none of the households surveyed reported the share of food expenditure in excess of $40 \%$.

On the other hand, place of residence slightly less differentiated the sample but it was a statistically significant relationship (Cramér's $\mathrm{V}=0.158, p \leq 0.01$ ). In addition, in Warsaw, there was the largest number of households where the share of food spending in their budgets reached $25 \%$.

\section{Frequency of food shopping in seniors' households}

The findings concerning how often the elderly buy food confirm that the seniors surveyed can be considered as active consumers. Every fourth respondent does shopping every day, more than $2 / 5$ of seniors - a few times a week, every third - once a week, and only $2 \%$ of all respondents shop less frequently. It can thus be stated that as many as $66 \%$ of the elderly are active consumers who systematically visit both small shops and local bazaars as well as shopping malls and shopping centres.

This frequency depends on the age of respondents (Kendall's tau-b coefficient $=0.177$ for $p \leq 0.010$ Young old seniors do shopping far more often than 
the oldest old. In the 65-74 age group, more than 3/5 state that they shop for food every day, which may be said for every third respondent in the 75-84 age group and for only one in ten oldest old respondents.

Seniors' education is another variable that statistically significantly influences the frequency of shopping done by those aged 65+ (Kendall's tau-b coefficient $=0.157$ for $p \leq 0.010$ It has been found that the higher the educational level is, the more frequently food is purchased. Hence, it is not surprising that more seniors with higher education say that they do shopping every day than those with primary education do. The survey reveals that women state that they tend to shop for food daily more frequently than men (Kendall's tau-b coefficient $=0.137$ for $p \leq 0.010$ In addition, better financial situation of seniors is directly reflected as more frequent shopping (Kendall's tau-b coefficient $=0.124$ for $p \leq 0.010$ Food is bought every day by almost every second respondent with a monthly income of more than PLN 3000 per capita and by every third senior with a monthly income of PLN 3001-4000 per person. Only one in ten respondents aged 65+ with a monthly income per capita of less than PLN 2000.00 declares daily shopping. This group of seniors shop for food once or a few times a week.

Based on the analysis of the research material, it can be stated that the financial situation of the seniors surveyed had a major effect on the shopping frequency if price reductions were offered (Kendall's tau-b coefficient was 0.126 for $p \leq 0.010$. The better the financial situation of people aged $65+$ was, the less numerous the respondents driven by discounts were. The survey demonstrates that more frequent food purchases motivated by price reductions were reported by seniors in a bad and very bad financial situation (69.3\%), by more than $2 / 5$ of respondents assessing their financial situation as good, and by almost every ninth respondent in a very good financial situation.

As for sex, according to the traditional division of shopping-related roles in the Polish family, women more commonly buy food products. Over $3 / 5$ of those interviewed were of the opinion that decisions about food purchases were made by women in their households. Only one in five seniors claimed that such decisions were made jointly.

It was also noted that food products were bought by seniors attending courses at Universities of the Third Age (UTA) more often than by those who were members of parochial communities (Kendall's tau-b coefficient was 0.143 for $p \leq 0.01$.

The survey reveals that the place of residence of older people is not a statistically significant variable that affects the frequency of shopping. It appears that senior inhabitants of Warsaw, Kraków, Poznań and Wrocław most often declare that they buy food daily, whereas the elderly from Białystok and Lublin do this least frequently. 


\section{Consumption of food products in seniors' households}

Consumption of most food products depends largely on the disposable income of seniors. As the wealth of their households increases, the level of consumption of certain foods rises too. Compared with the lowest-income families (up to PLN 2000 per person), seniors' households earning a monthly per capita income of over PLN 4000 consumed over three times more fruit and vegetable juices, yoghurt and milk drinks, almost two and a half times more fish and vegetables, and nearly twice more fruit. On the other hand, seniors with the lowest incomes ate more bread, flour, potatoes, and sugar. Furthermore, regardless of household wealth, over $1 / 3$ of seniors claimed to successively abstain from consumption of animal fats, including butter, in favour of vegetable fats. Such behaviour is undoubtedly a manifestation of changes in nutritional patterns, whereby animal fats are being ever more frequently replaced by fats that do not contain the cholesterol that may be harmful to the human body.

It was also noted that UTA students were more likely to consume groats and flakes, vegetables and fruit, yoghurt and milk drinks, fish, fruit and vegetable juices, and less likely to consume bread, animal fats, eggs, milk and potatoes than senior members of parochial communities.

Current nutritional habits are much affected by the pursuit of comfort, routines, desire to gain certain benefits for a given price, care about health, hedonism, and individual respect for customary norms [Vermeir and Verbeke 2004, p. 37, Vermeir and Verbeke 2006, pp. 177-178; Minteer, Corley and Manning 2004, pp. 142-144]. Consumer decisions concerning food should not, however, disregard the basic determinants of choice, in particular needs, preferences, and possibilities of their satisfaction [Meulenberg 2003, pp. 47-48].

Food consumption is correlated with the place of residence (Table 2). There are differences in the patterns of food consumption between seniors living in various Polish cities. The survey results indicate that the most bread and grain products were consumed per capita by inhabitants of Lublin $(5.26 \mathrm{~kg})$ and Białystok $(5.25 \mathrm{~kg})$, and the least by those living in Gdańsk $(4.59 \mathrm{~kg})$ and Torun $(4.59$ $\mathrm{kg})$. The biggest amounts of groats and flakes were eaten per capita by seniors living in Poznań $(0.62 \mathrm{~kg})$, whereas the lowest by people aged $65+$ living in Łódź $(0.42 \mathrm{~kg})$. The per capita intake of meat and meat products was the highest in Katowice $(7.98 \mathrm{~kg})$, and the lowest in Warsaw $(5.96 \mathrm{~kg})$. In turn, the most milk was consumed per person in Łódź (4.32 1), while the least in Wrocław (3.57 1). The per capita intake of yoghurt and milk drinks was the highest for senior inhabitants of Warsaw (0.73 1), and the lowest for those in Katowice (0.42 1). The biggest amounts of fish were consumed per capita by seniors living in Warsaw $(0.67 \mathrm{~kg})$, and the lowest by inhabitants of Lublin $(0.36 \mathrm{~kg})$. 


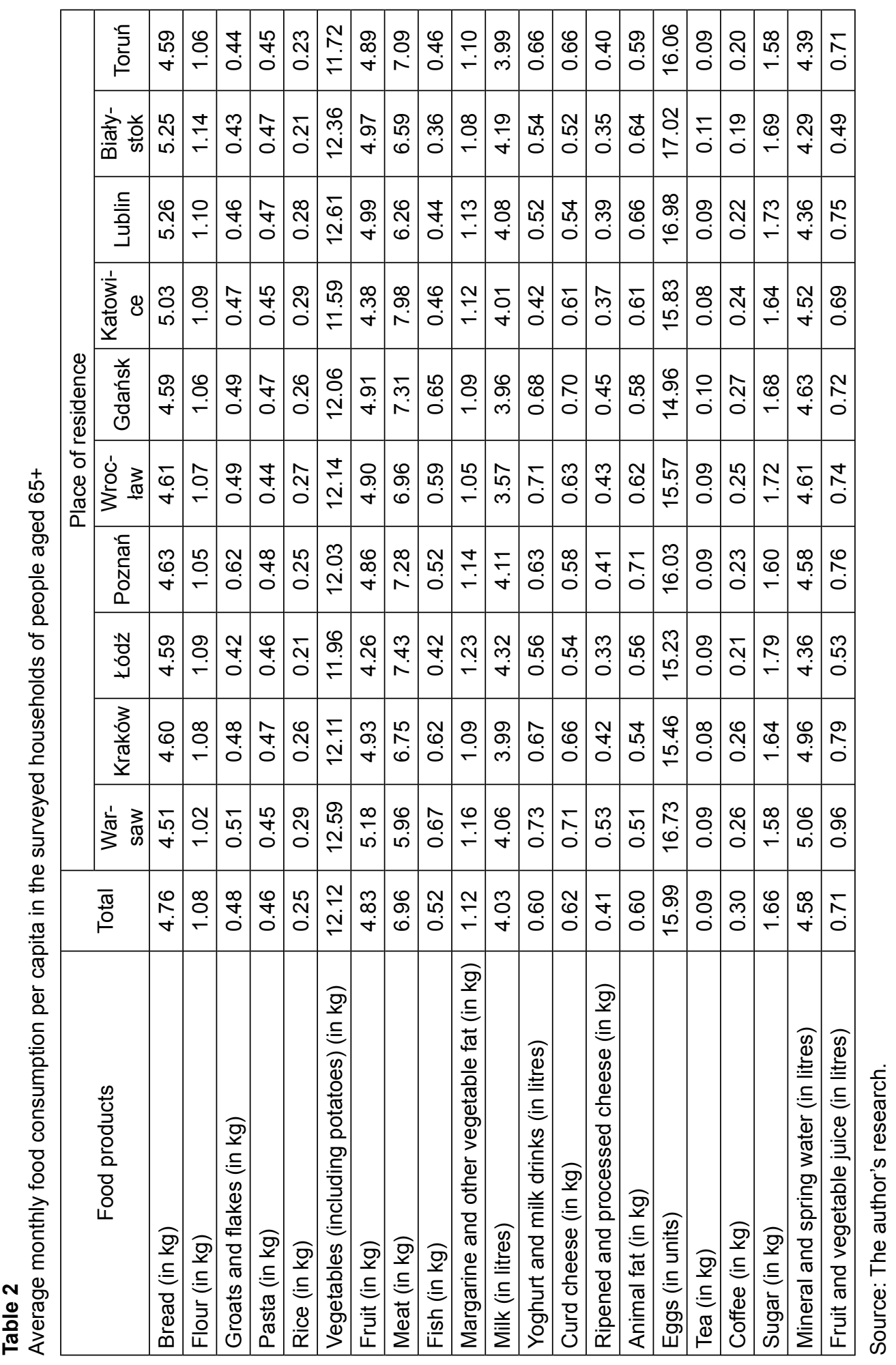


The highest per capita consumption of fruit was recorded in Warsaw $(5.18 \mathrm{~kg})$ and the lowest in Łódź $(4.26 \mathrm{~kg})$, whereas vegetables were most frequently consumed by seniors living in Lublin $(12.61 \mathrm{~kg})$ and least frequently by those living in Torun (11.72 kg). As far as fruit and vegetable juices are concerned, the highest per capita intake was noted for senior inhabitants of Warsaw (0.96 1), and the lowest for those living in Białystok (0.49 1).

In the context of the survey, it can be concluded that the average monthly food intake is not an expression of a satisfactory standard of living of seniors' households but rather a consequence of the need to spend more money on other purposes, chiefly accommodation. This is particularly true of urban households that are dependent on government policies with respect to housing charges. It should be noted here that the analysis of the average monthly consumption of food per person does not allow clear conclusions to be drawn as to food consumption patterns in individual cities.

\section{Determinants affecting seniors' food purchase decisions}

While shopping for food, senior consumers attach considerable importance to freshness, quality, origin and promotion of food products, whereas they care less about brand, advertising and completeness of the offer (Table 3). In the light of the research, such findings are not surprising.

The primary survey shows that seniors are primarily driven by the price of a product when buying food. It was indicated by more than $4 / 5$ of respondents. This situation is not surprising, given that the financial situation of the elderly is difficult and that they spend a significant portion of their disposable income on food. Based on the empirical material collected, it was observed that women mentioned price as the fundamental factor in purchasing food products slightly more frequently than men $(85.5 \%$ and $79.2 \%$ respectively). It was also noted that the views of the seniors interviewed were influenced by their age. Price was least often declared as the most important factor by the youngest respondents, aged 65-74 (53.2\%), while it was most frequently mentioned by those aged 85 and more $(91.4 \%)$. The level of education is another variable that differentiates the opinions of the study population on the impact of prices on decisions to purchase food products. Mostly people with primary $(95.8 \%)$ and basic vocational (93.7\%) education declared that the product price was of fundamental importance. The survey also noted that respondents participating in parochial communities $(89.9 \%)$ paid the greatest attention to the product price more often than UTA students $(73.3 \%)$. 
Table 3

Determinants of food purchases in the seniors' households surveyed (in \%)

\begin{tabular}{|l|c|c|c|}
\hline \multicolumn{1}{|c|}{ Items } & Very important & Important & Not important \\
\hline Price & 81.6 & 14.9 & 3.5 \\
\hline Quality & 65.3 & 29.8 & 4.9 \\
\hline Utility & 46.3 & 53.7 & - \\
\hline Brand & 29.3 & 55.6 & 15.1 \\
\hline Fashion & 13.5 & 40.3 & 46.2 \\
\hline Promotions & 55.8 & 30.7 & 13.5 \\
\hline Shopping location & 33.2 & 49.8 & 17.0 \\
\hline Product packaging & 26.1 & 53.4 & 20.5 \\
\hline Habit & 15.9 & 44.3 & 39.8 \\
\hline Wish to stand out & 2.9 & 12.5 & 84.6 \\
\hline Advertising & 30.1 & 56.0 & 13.9 \\
\hline
\end{tabular}

Source: The author's research.

More than $3 / 5$ of seniors indicated product quality as the key factor when shopping for food products (especially organic food). The significance of product quality increases as the income rises. Wealthier consumers, who are inherently more demanding, aspiring and curious, are interested in buying better product substitutes or more luxurious products. Indeed, this is confirmed by the direct research. The greatest interest in better quality goods was demonstrated by the wealthiest households with monthly disposable incomes of more than PLN 4000 per capita, and vice versa: the lower the income, the less important the product quality (Kendall's tau-b coefficient was 0.225 for $p \leq 0.01$. It should be pointed out here that quality is a set of advantages and disadvantages of a particular food product as viewed by consumers themselves. Hence, as a typical immeasurable feature, it is purely subjective and is assessed by a specific person. Age again proved to be a variable differentiating respondents' opinions in this regard. Quality as the fundamental factor in buying food products was most commonly mentioned by those in the $65-74$ age group $(72.1 \%)$, and least frequently by respondents aged 85 and more (36.6\%). The level of education also varies respondents' opinions on the meaning of quality of purchased food products. Quality as a driver was most often mentioned by university graduates (75.3\%), and least frequently by those with primary education $(24.7 \%)$. It was also noted that product quality was indicated as the essential determinant when shopping for food by UTA students (71.2\%). Only 59.4\% of senior members of parochial communities pointed to this factor. 
Promotions and utility of products purchased are also important to nearly $2 / 3$ and almost half of respondents respectively. Most often, these factors were indicated as key determinants of purchasing food products by seniors aged 65-74 (57.3\%) who had completed secondary education (56.7\%), earned a monthly per capita income of up to PLN 4000 (59.2\%), and actively participated in UTA courses $(59.2 \%)$.

Every third senior interviewed mentioned brand, advertising and product packaging as factors that played a vital role when shopping. The distribution of answers varied depending largely on household (33.8\% in the wealthiest households to $9.7 \%$ in the poorest households with up to PLN 2000 per capita), educational level (36.6\% of responses among people with higher education, and the smallest proportion among respondents with primary education $-7.3 \%$ ), age (brand was most frequently mentioned as the fundamental factor when shopping for food by respondents aged 65-74, and least often by those aged 85 and more). It was also noticed that UTA students $(35.8 \%)$ rather than parochial community members $(21.2 \%)$ that paid great attention to factors such as brand, advertising and product packaging when buying food. Significantly fewer respondents pointed to: habit (15.9\%), fashion (13.5\%) and the wish to stand out (2.9\%).

Seniors most often buy food such as: dairy products, hard cheeses, eggs and bread in corner and discount shops (mostly in Biedronka, Lidl and Aldi). As for fruit, vegetables and meat, seniors' requirements are best satisfied by local markets and bazaars, given that such products must be fresh and of better quality. By contrast, larger amounts of food (mostly groats, rice, flour, pasta, vegetable and animal fats, yoghurt, cream, milk, coffee and tea) are most frequently bought in hypermarkets and supermarkets.

\section{Conclusion}

Food needs are the most urgent and most strongly felt needs of households' members. In the case of food products, their consumption largely depends on the disposable income of seniors. Compared to the lowest-income families, the most affluent households of seniors consume more fruit and vegetable juices, yoghurt and milk drinks, fish, and fruit and vegetables. On the other hand, the lowestincome households buy more bread, flour, potatoes, and sugar. Furthermore, regardless of income, over $1 / 3$ of seniors' households are successively replacing animal fats, including butter, with vegetable fats. Such behaviour of people aged $65+$ obviously confirms that they are taking care of their health and are reducing the intake of cholesterol that is harmful to the human body. 
The research results concerning the decision-making process indicate that prudent decisions are dominant purchasing decisions made by those aged 65+. In a more or less conscious way, they adopt a decision-making strategy that is targeted at a specific choice. The seniors surveyed mostly buy well known and often used products. Another characteristic of the majority of respondents is the wish to avoid uncertain situations. This applies to the purchase of food products. When buying them, seniors attach considerable importance to the freshness, quality and origin of the product, whereas they care less about advertising, completeness of the offer and shopping location.

\section{References}

ALDERFER C.P., 1972: Existence, Relatedness and Growth, Free Press, New York.

GUTKOWSKA K., OZIMEK I., LASKOWSKI W., 2001: Uwarunkowania konsumpcji w polskich gospodarstwach domowych [Determinants of Consumption in Polish Households], Wydawnictwo Szkoły Głównej Gospodarstwa Wiejskiego, Warsaw.

MASLOW A.H., 1954: Motivation and Personality, Harper and Row, New York.

MAX-NEEF M.A., 1991: Human Scale Development. Conception, Application and Further Reflections, The Apex Press, New York - London.

MEULENBERG M.T.G., 2003: Consumer and Citizen. Meaning for the Market of Agricultural Products and Food Products, Tijdschrift voor Sociaal Wetenschappelijk Onderzoek van de Landbouw, 18 (1), 43-56.

McCLELLAN D.C., 1975: Power: The Inner Experience, Halstead, New York.

MINTEER B.A., CORLEY E.A., MANNING R.E., 2004: Environmental Ethics Beyond Principle? The Case for a Pragmatic Contextualism, Journal of Agricultural and Environmental Ethics, 17 (2), 131-156.

TSAI A.C., LIOU J-C., CHANG M-C., 2006: Food Patterns that Correlate to Health and Nutrition Status in Elderly Taiwanese, Nutrition Research, 26 (2), 71-76.

VERMEIR I., VERBEKE W., 2004: Sustainable Food Consumption, Involvement, Certainly and Values: an Application of the Theory of Planned Behavior, Working Paper, Department of Agricultural Economics, Ghent University, Ghent.

VERMEIR I., VERBEKE W., 2006: Sustainable Food Consumption: Exploring the Consumer, "Attitude - Behavioral Intention" Gap, Journal of Agricultural and Environmental Ethics 19.

ZALEGA T., 2011: Spożycie żywności w gospodarstwach domowych z osobami bezrobotnymi na Mazowszu [Food Consumption in Masovian Households with Unemployed Members], Zeszyty Naukowe Szkoły Głównej Gospodarstwa Wiejskiego. Ekonomika i Organizacja Gospodarki Żywnościowej 93, 119-135.

ZALEGA T., 2012: Konsumpcja. Determinanty, teorie, modele [Consumption. Determinants, Theories and Models], PWE, Warsaw.

ZALEGA T., 2013: Spożycie produktów żywnościowych $w$ wielkomiejskich gospodarstwach domowych $w$ Polsce w okresie kryzysu finansowo-ekonomicznego [The Consumption of 
Foodstuffs of Large-city Households in Poland During Financial and Economic Crisis], Problemy Zarządzania 11, 1 (40), 1, 68-87.

ZALEGA T., 2016: Segment osób $w$ wieku 65+ w Polsce. Jakość życia, konsumpcja, zachowania konsumenckie [People Aged 65+ in Poland. Quality of Life, Consumption, Consumer Behaviour], Wydawnictwo Naukowe WZ UW, Warsaw.

\section{Abstract}

This article addresses consumption of food products in seniors' households. The primary goal is to analyse their food expenditure, shopping frequency and the key factors affecting their decisions in this regard. The analysis is based on the questionnaire survey conducted by the author in 2014-2015 among people aged $65+$ in Poland.

The structure of the article is as follows. After a synthetic discussion of the research methodology, assumptions, and the characteristics of the research sample, a very broad theoretical outline of food consumption in seniors' households is presented. Further, the focus is on examining food consumption in the seniors' households surveyed, shopping frequency, and the key determinants taken into consideration by people aged $65+$ when deciding to buy food products.

Key words: consumption, seniors, purchasing decisions, food products

\section{Uwarunkowania wyboru wybranych produktów spożywczych w wielkomiejskich gospodarstwach domowych seniorów w Polsce}

\section{Streszczenie}

Artykuł podejmuje problem konsumpcji produktów żywnościowych w gospodarstwach domowych seniorów. Podstawowym celem tekstu jest przeanalizowanie wydatków na żywność gospodarstw domowych seniorów, częstotliwości robienia zakupów oraz kluczowych czynników wpływających na decyzje osób starszych w tym zakresie. Podstawą analizy jest wywiad kwestionariuszowy przeprowadzony przez autora w latach 2014-2015 wśród osób w wieku 65+ w Polsce.

Struktura artykułu jest następująca. Po syntetycznym omówieniu metodologii i założeń badania oraz charakterystyki próby badawczej, w ujęciu teoretycznym, naświetlono, w sposób bardzo ogólny, zagadnienie konsumpcji żywności w gospodarstwach domowych osób starszych. W dalszej części tekstu skoncen- 
trowano się na przeanalizowaniu spożycia żywności w badanych gospodarstwach seniorów, częstotliwości dokonywania zakupów, a następnie na kluczowych determinantach branych pod uwage przez osoby w wieku $65+$ przy podejmowaniu decyzji zakupu produktów żywnościowych.

Słowa kluczowe: konsumpcja, seniorzy, decyzje zakupowe, produkty żywnościowe 